\title{
IDENTIFIKASI KONSEP STANDAR DAN PENYAJIAN LAPORAN KEUANGAN PADA ENTITAS MIKRO
}

\author{
Mutiara Puspa Widyowati
}

Fakultas Ekonomi Universitas Pakuan

Email: puspa.widyowati@gmail.com

\author{
ARTICLE INFO \\ Article History \\ Received 1 December 2018 \\ Revised 15 December 2018 \\ Accepted 10 January 2019 \\ JEL Classification \\ M42 \\ Kata Kunci: \\ Entitas Mikro, \\ Karakteristik Entitas Mikro, \\ Kebutuhan Informasi \\ Pengguna Laporan \\ Keuangan, dan \\ Konsep dan Penyajian \\ Laporan Keuangan Entitas \\ Mikro
}

\begin{abstract}
Abstrak
Standar Akuntansi Keuangan Untuk Entitas Tanpa Akuntabilitas Publik (SAK-ETAP) merupakan standar yang disahkan untuk diimplementasikan pada entitas tanpa akuntabilitas publik termasuk didalamnya entitas mikro. Namun, standar tersebut kurang sesuai khususnya untuk entitas mikro karena dianggap masih terlalu rumit. Hal ini dibuktikan dengan beberapa penelitian yang menunjukkan rendahnya penerapan standar tersebut oleh entitas kecil dan menengah khususnya entitas mikro. SAK ETAP lebih cenderung sesuai untuk entitas tanpa akuntabilitas publik yang memiliki skala besar, bukan untuk entitas yang memiliki skala kecil. Terkait dengan hal tersebut untuk membantu Entitas Mikro, Kecil, dan Menengah (EMKM) agar dapat menyajikan laporan keuangan, DSAK IAI telah mengesahkan exposure draft Standar Akuntansi Keuangan Entitas Mikro, Kecil, dan Menengah (SAK EMKM) dengan konsep yang lebih sederhana dibandingkan dengan SAK ETAP. Penelitian ini berusaha mengidentifikasi dan mengklasifikasi karakteristik entitas mikro dan kebutuhan informasi keuangan dari pengguna laporan keuangan entitas mikro. Melalui analisis karakteristik dan kebutuhan informasi tersebut dapat dilakukan analisis konsep standar yang sesuai untuk entitas mikro. Hasil penelitian menunjukkan bahwa entitas mikro memiliki karakteristik antara lain, memliki jumlah contract partner yang sedikit (umumnya pemilik, pihak bank, dan pemerintah), transaksi bisnis yang sederhana, serta rendahnya pengetahuan pemilik mengenai penyajian laporan keuangan untuk pihak luar. Kebutuhan informasi dari entitas mikro, yaitu informasi arus kas masuk dan keluar dan informasi yang berkaitan dengan kinerja. Dengan demikian, konsep standar yang dibutuhkan oleh entitas mikro, yaitu asumsi dasar pengakuan transaksi menggunakan dasar kas. Entitas mikro hanya perlu membuat dua laporan keuangan utama, yaitu laporan laba rugi dan laporan posisi keuangan.
\end{abstract}




\section{PENDAHULUAN}

Usaha Mikro, Kecil, dan Menengah yang selanjutnya disebut UMKM dianggap telah memberikan kontribusi yang cukup besar terhadap perekonomian terutama di negaranegara berkembang. Di Indonesia jumlah UMKM dapat membantu pemerintah untuk penanggulangan masalah kemiskinan dengan menyediakan lapangan pekerjaan baru dan menjadi salah satu sumber pemasukan pemerintah melalui pembayaran pajak.

Salah satu faktor yang mempengaruhi perkembangan usaha mikro dan kecil adalah mengenai keterbatasan permodalan (Suthapa, 2008). Modal usaha mikro pada umumnya berasal dari modal pemilik sendiri yang cenderung kecil jumlahnya. Pada dasarnya telah banyak akses bagi entitas ini untuk mendapatkan suntikan modal, misalnya melalui program Kredit Usaha Rakyat (KUR) dari pemerintah dan kredit dari bank-bank swasta. Namun demikian, Rudiantoro, Rizki Siregar (2011) menyatakan bahwa penyaluran KUR cukup rendah karena bank yang ditunjuk kesulitan mendapatkan akses informasi terkait dengan UMKM. Hal ini sesuai dengan yang disampaikan oleh Suthapa (2008), bahwa salah satu kendala eksternal perkembangan BPR adalah nasabah kredit (entitas mikro dan kecil) yang belum mampu memenuhi persyaratan baik dari sisi sumber daya manusia, pencatatan hasil usaha, permodalan maupun penyediaan jaminan tambahan. Banyak entitas mikro dan kecil yang layak untuk mendapatkan bantuan modal namun terkendala persyaratan administrasi.

Untuk memenuhi kebutuhan informasi keuangan bagi UKM, pada tahun 2011 Dewan Standar Akuntansi Keuangan (DSAK) Ikatan Akuntan Indonesia telah mensahkan Standar Akuntansi Keuangan Untuk Entitas Tanpa Akuntabilitas Publik (SAK-ETAP). Standar ini merupakan adopsi dari International Financial Reporting Standard for Small Medium

\footnotetext{
${ }^{1}$ Data Perkembangan Usaha Mikro, Kecil, dan Menengah (UMKM) dan Usaha Besar (UB) yang diperoleh dari
}

Sebagian besar dari jumlah UMKM di Indonesia didominasi oleh usaha pada sektor mikro, yaitu sebesar $98 \%$ dari seluruh jumlah $\mathrm{UMKM}^{1}$. Hal ini menunjukkan kontribusi yang cukup besar tersebut diberikan oleh entitas mikro terutama dalam penyerapan tenaga kerja. Namun demikian, di Indonesia belum banyak penelitian mengenai UMKM yang mengkhususkan penelitian pada entitas mikro maka pembahasan ini akan berfokus pada UMKM di sektor mikro.

Enterprises (IFRS for SMES) dengan berbagai penyederhanaan. Namun, sejak disahkan sampai saat ini masih menunjukkan implementasi SAK ETAP yang belum maksimal oleh para pelaku UMKM. Kecuali diwajibkan banyak pelaku UMKM yang tidak menerapkan SAK ETAP atau bahkan tidak memiliki pencatatan. Penelitian yang dilakukan di Zimbabwe (Maseko, 2011), Ghana (Amoako, 2013) dan Sunyani (Amoah \& Samuel, 2014) serta di Indonesia yaitu di daerah Jawa Barat (Rudiantoro, Rizki \& Siregar, 2011) dan di Kota Semarang (Syarifah, 2012) masih menunjukkan rendahnya penerapan standar tersebut. Sebagian besar penelitian menunjukkan rendahnya pengetahuan dan kurangnya informasi menyebabkan rendahnya motivasi untuk menerapkan standar pelaporan.

Banyak penelitian yang menyebutkan standar tersebut masih belum sesuai diterapkan pada entitas mikro karena dianggap terlalu rumit. Pada umumnya entitas mikro sifat dan tujuannya lebih kepada bertahan hidup dan menjaga kestabilan usahanya sedangkan usaha yang lebih besar dari entitas mikro lebih bertujuan pada pertumbuhan dan maksimalisasi laba. Neag (2009), menyatakan bahwa secara tidak langsung IFRS for SME lebih cenderung sesuai untuk entitas tanpa akuntabilitas publik yang memiliki skala besar, bukan untuk entitas yang memiliki skala kecil.

Terkait dengan hal tersebut untuk membantu Entitas Mikro, Kecil, dan Menengah

Departemen Perkoperasian. Proporsi usaha kecil sebesar $1,11 \%$, usaha menengah sebesar $0,09 \%$, dan usaha besar sebesar $0,01 \%$. 
(EMKM) untuk dapat menyajikan laporan keuangan, DSAK IAI telah mengesahkan Standar Akuntansi Keuangan Entitas Mikro, Kecil, dan Menengah (SAK EMKM) dengan konsep yang lebih sederhana dibandingkan dengan SAK ETAP. Standar ini diharapkan dapat membantu EMKM untuk dapat menyusun laporan keuangan dengan lebih mudah karena tidak serumit SAK ETAP. Namun demikian, klasifikasi EMKM di Indonesia yang didasarkan pada UU No. 28 Tahun 2008 belum dapat memisahkan entitas mikro dengan entitas kecil dan menengah. Entitas mikro di Indonesia merupakan entitas dengan skala terkecil dan memiliki karakteristik yang berbeda dengan entitas yang skalanya lebih besar.

Neag (2009) menyebutkan bahwa penting untuk memahami kebutuhan informasi yang khusus dari entitas mikro. Bisnis kecil pada umumnya tidak membutuhkan pencatatan dan peraturan pencatatan yang terlalu rumit sehingga pembuat standar dan regulator harus memahami perbedaan antara entitas besar dan kecil (Neag, 2009). Pengguna laporan pada UKM cenderung tidak membutuhkan laporan keuangan yang rumit dan analisis laporan keuangan yang mendalam. Namun cenderung lebih pada menilai pada efektivitas manajemen dan kemampuan menghasilkan arus kas yang positif. Penelitian ini mengacu pada pengidentifikasian karakteristik entitas mikro dan kebutuhan pengguna informasi keuangan dari entitas mikro yang selanjutnya dapat dijadikan dasar untuk menyusun konsep pencatatan keuangan yang tepat.

Dengan demikian, penelitian ini berusaha melakukan identifikasi karakteristik entitas mikro dan kebutuhan informasi pengguna laporan keuangan entitas mikro yang kemudian melakukan analisis penyajian informasi keuangan dan konsep standar pelaporan keuangan entitas mikro agar dapat memenuhi kebutuhan pengguna informasi keuangan entitas mikro. Dengan demikian dapat dinilai kesesuaian dari standar EMKM untuk diterapkan pada entitas mikro.

\section{TELAAH TEORITIS}

\section{Entitas Mikro}

Di berbagai negara usaha mikro didefinisikan atau dikriteriakan secara beragam. Belum ada definisi untuk UMKM yang dapat diterima secara universal (Mawardi, 2014). Dalam beberapa definisi, pada umumnya bisnis kecil atau mikro dilihat sebagai bisnis yang mempekerjakan sedikit pegawai dan memiliki modal dan perputaran modal yang relatif kecil (Mbroh, 2011). International Labour Organization (ILO,1997) menyatakan bahwa tidak ada definisi tunggal yang dapat merekam dan merefleksikan seluruh dimensi bisnis mikro, kecil, maupun menengah pada tingkat perkembangan negara yang berbeda. Misalnya bisnis dengan perputaran kurang dari USD 100.000 dapat dikategorikan sebagai usaha mikro di Amerika namun di negara lain khususnya di negara berkembang bisnis tersebut dapat dikategorikan sebagai bisnis menengah.

Dalam hal ini World Bank mendefinisikan entitas mikro dengan bisnis yang memiliki jumlah karyawan kurang dari 10 orang, pendapatan per tahun kurang dari $\$ 100.000$ yang jumlah aset kurang dari $\$ 100.000$. Sedangkan European mengklasifikasikan entitas mikro dengan karyawan kurang dari 10 orang, pendapatan per tahun kurang dari $\$ 2.000 .000$ dan jumlah aset kurang dari \$ 2.000.000. Sedangkan beberapa negara lainnya tidak mengklasifikasikan UMKM berdasar pada sektor mikro, kecil, atau menengah. Negaranegara Asia juga tidak memiliki definisi standar untuk UMKM, seperti yang ditunjukkan pada tabel di bawah ini. Namun, dari seluruh definisi yang dibuat oleh beberapa negara, walaupun dengan nilai yang berbeda menunjukkan bahwa entitas mikro merupakan entitas terkecil dalam entitas bisnis.

Di Indonesia terdapat berbagai macam klasifikasi UMKM yang dilakukan oleh berbagai lembaga. Kementrian Negara Koperasi dan Usaha Kecil Menengah (Kemenegkop dan UKM) mengklasifikasikan Usaha Kecil (UK), 
termasuk Usaha Mikro (UMI), dengan kekayaan bersih kurang dari Rp200.000.000 tidak termasuk tanah dan bangunan tempat usaha dan dengan penjualan tahunan tidak lebih dari Rp1.000.000.000. Usaha Menengah (UM) diklasifikasikan dengan usaha yang memiliki kekayaan bersih kurang dari Rp200.000.000 dan penjualan tahunan kurang dari $\mathrm{Rp}$ 10.000.000.000 tidak termasuk tanah dan bangunan. Undang-undang Nomor 20 Tahun 2008 tentang Usaha Mikro Kecil dan Menengah mengklasifikasikan usaha mikro kecil dan menengah sebagai berikut.

Tabel 1. Klasifikasi Usaha Mikro Kecil dan Menengah Berdasarkan Undang-undang Nomor 20 tahun

\begin{tabular}{lll}
\hline Entitas & $\begin{array}{l}\text { Kekayaan } \\
\text { Bersih }\end{array}$ & $\begin{array}{l}\text { Pendapatan } \\
\text { per Tahun }\end{array}$ \\
\hline Mikro & Kurang dari & Kurang dari \\
& Rp50 juta & Rp300 juta \\
\hline Kecil & Lebih dari & Lebih dari \\
& Rp50 juta - & Rp300 juta - \\
& Rp500 juta & Rp2,5 miliar \\
\hline Menengah & Lebih dari & Lebih dari \\
& Rp500 juta - & Rp2,5 miliar - \\
& Rp100 miliar & Rp50 miliar \\
\hline
\end{tabular}

Mawardi (2014) menyatakan bahwa walaupun kriteria secara kuantitatif ini cenderung bervariasi antar negara namun definisi berdasarkan kriteria ini banyak digunakan oleh institusi-institusi dan pemerintah. Hal ini karena definisi dengan kriteria kuantitatif cenderung sederhana dan objektif.

\section{Pentingnya Laporan Keuangan pada Entitas Mikro}

Banyak penelitian yang menunjukkan bahwa kegagalan usaha dari UMKM adalah karena buruknya sistem akuntansi yang digunakan oleh UMKM. Amoako (2013) menyatakan bahwa pentingnya mengevaluasi sistem akuntansi pada UMKM untuk pertumbuhan yang optimum. Sistem akuntansi dapat membantu dalam menentukan jumlah penjualan, mengetahui adanya laba (rugi), jumlah aset dan kewajiban pada suatu periode.

Proses pengungkapan laporan keuangan dapat mengurangi asimetri informasi antara pihak dari dalam perusahaan dengan pihak eksternal yang berkepentingan dengan perusahaan (Fulbier dan Gassen, 2010). Hal ini berkaitan dengan teori kontrak (contract theory) dalam perusahaan. Orang-orang mengumpulkan sumber daya yang mereka punya pada suatu perusahaan dengan didasarkan pada suatu kontrak atau ikatan (Alchian dan Demsetz, 1972). Kontribusi sumber daya tersebut dilakukan untuk suatu tujuan umum, yaitu realisasi laba perusahaan yang dapat memenuhi kepuasan tujuan masing-masing pihak (Fulbier dan Gassen, 2010). Misalnya, gaji untuk karyawan, kompensasiuntuk manajer, dan bunga untuk kreditur. Untuk itu, perusahaan harusdirancang untuk dapat mengurangi biaya kontrak atau biaya transaksi.

Tanpa adanya laporan keuangan dan tanpa adanya perlindungan alternatif lainnya, pihak yang memiliki kontrak dengan perusahaan akan merasa kekurangan informasi yang mengacu pada tingginya asimetri informasi. Pihak-pihak tersebut akan cenderung menyesuaikan tuntutan kontraktual dengan perusahaan baik dengan meningkatkan beban resiko atau justru mengundurkan diri dari kontrak (Fulbier dan Gassen, 2010). Kreditur yang tidak memiliki informasi yang cukup mengenai perusahaan akan memiliki tingkat resiko yang tinggi. Hal ini kemudian berkaitan langsung dengan pengenaan bunga kredit yang tinggi sebagai kompensasi atas tingginya resiko tersebut.

Standar Akuntansi untuk Entitas Tanpa Akuntabilitas Publik dan Exposure Draft Standar Akuntansi Keuangan Entitas Mikro, Kecil, dan Menengah

Untuk membantu UMKM dalam pelaporan keuangan dewan standar akuntansi di Indonesia mensahkan Standar Akuntansi untuk Entitas Tanpa Akuntabilitas Publik (SAK 
ETAP). Standar ini merupakan adopsi dari IFRS for SMEs yang diharapkan dapat mengakomodir kebutuhan UMKM yang membutuhkan standar yang lebih sederhana dari Standar Akuntansi Keuangan (SAK) umum. Standar ini telah berlaku secara efektif sejak 1 Januari 2011.

Ruang lingkup standar ini dimaksudkan untuk digunakan entitas tanpa akuntabilitas publik, yaitu entitas yang tidak memiliki akuntabilitas publik signifikan dan entitas yang menerbitkan laporan keuangan untuk tujuan umum bagi pengguna eksternal. Selain itu, entitas yang memiliki akuntabilitas publik signifikan dapat menggunakan SAK ETAP jika otoritas berwenang membuat regulasi mengizinkan penggunaan SAK ETAP. Bank Perkreditan Rakyat merupakan contoh entitas yang memiliki akuntabilitas publik signifikan yang menggunakan SAK ETAP mulai 1 Januari 2010.

Dalam SAK-ETAP disebutkan bahwa tujuan laporan keuangan adalah menyediakan informasi posisi keuangan, kinerja keuangan, dan laporan arus kas suatu entitas yang bermanfaat bagi sejumlah besar pengguna dalam pengambilan keputusan ekonomi. Dalam memenuhi tujuannya, laporan keuangan juga menunjukkan apa yang telah dilakukan manajemen (stewardship) atau pertanggungjawaban manajemen atas sumber daya yang dipercayakan kepadanya.

Di dalam SAK ETAP disebutkan bahwa laporan keuangan entitas terdiri dari beberapa laporan sebagai berikut.

1. Laporan posisi keuangan yang terdiri dari unsur aset, liabilitas, dan ekuitas.

2. Laporan laba rugi atau merupakan laporan kinerja keuangan entitas terdiri dari unsur penghasilan dan beban.

3. Laporan perubahan ekuitas yang menunjukkan seluruh perubahan dalam ekuitas atau perubahan ekuitas selain perubahan yang timbul dari transaksi dengan pemilik dalam kapasitasnya sebagai pemilik.
4. Laporan arus kas, yang terdiri dari kas yang berasal dari aktivitas operasi, aktivitas investasi, dan aktivitas pendanaan.

5. Catatan atas laporan keuangan yang berisi ringkasan kebijakan akuntansi yang signifikan dan informasi penjelasan lainnya.

Laporan keuangan kecuali laporan arus kas disusun dengan menggunakan dasar akrual. Dalam dasar akrual, unsur-unsur dalam laporan keuangan diakui saat terjadinya transaksi dan bukan saat sejumlah rupiah dari transaksi tersebut diterima. Dasar pengukuran setiap pos dalam laporan keuangan tersebut menggunakan dasar nilai historis dan nilai wajar. SAK ETAP yang merupakan adopsi dari IFRS for SME dirasa masih belum sesuai dengan usaha pada sektor mikro. SAK-ETAP memang ditujukan bagi entitas tanpa akuntabilitas publik namun peruntukannya lebih cocok untuk entitas besar yang tidak memiliki akuntabilitas publik daripada untuk entitas tanpa akuntabilitas publik yang skala usahanya cukup kecil seperti usaha mikro. Dalam penelitian Maseko (2011), menyatakan bahwa untuk bisnis kecil, biaya untuk menyesuaikan dengan standar IFRS akan membutuhkan biaya yang lebih besar daripada manfaatnya.

Terkait dengan hal tersebut untuk mewujudkan amanah dari Undang-undang Nomor 1 tahun 2013 tentang Lembaga Keuangan Mikro (LKM), yaitu mendukung entitas mikro, kecil, dan menengah Indonesia yang maju, mandiri, dan mampu mengakses sumber pendanaan industry keuangan, DSAK IAI menyiapkan Standar Akuntansi Keuangan Entitas Mikro, Kecil, dan Menengah (SAK EMKM). Standar tersebut ditujukan bagi EMKM dengan kriteria yang didasarkan pada Undangundang Nomor 20 tahun 2008 tentang Usaha Mikro, Kecil, dan Menengah.

Pada dasarnya, konsep dan prinsip pervasif pada SAK EMKM sama dengan yang ada pada SAK ETAP. Asumsi dasar yang mendasari adalah akuntansi dasar akrual dengan menerapkan prinsip pervasif dan konsep entitas bisnis. Namun, komponen 
laporan keuangan yang disajikan menjadi lebih sederhana, yaitu minimal menyajikan laporan posisi keuangan, laporan laba rugi, dan catatan atas laporan keuangan. Laporan keuangan tersebut tidak memiliki ketentuan tentang format atau urutan penyajian akun.

\section{METODOLOGI PENELITIAN Sumber Data}

Populasi untuk penelitian ini adalah seluruh entitas mikro yang berada di Kota Yogyakarta. Jumlah dan data populasi tersebut diperoleh dari Direktori Data Base UKM Daerah Istimewa Yogyakarta oleh Dinas Perindag Koperasi kota Yogyakarta. Sampel yang akan menjadi responden dalam penelitian ini akan dipilih menggunakan teknik nonprobability dengan metode purposive sampling berdasarkan kriteria sebagai berikut.

1. Entitas yang bergerak dalam bidang perdagangan.

2. Entitas mikro yang memiliki kekayaan bersih paling banyak Rp50.000.000,00 (lima puluh juta rupiah) tidak termasuk tanah dan bangunan tempat usaha; atau memiliki hasil penjualan tahunan paling banyak Rp300.000.000,00 (tiga ratus juta rupiah). Namun demikian, nilai nominal yang tercantum pada undang-undang tersebut dapat saja tidak sesuai akibat dari turunnya nilai mata uang selama delapan tahun.

3. Entitas mikro yang memiliki ijin usaha dan memilliki Nomor Pokok Wajib Pajak (NPWP).

4. Entitas mikro yang telah memiliki laporan keuangan atau catatan keuangan yang biasa dilakukan.

Selain itu, untuk mengidentifikasi kebutuhan pengguna laporan keuangan entitas mikro penelitian ini juga melibatkan pihakpihak yang berkepentingan dengan entitas mikro terkait. Menurut Fulbier dan Gassen (2010) kreditur merupakan salah satu pihak pengguna laporan keuangan yang mendominasi bagi usaha kecil sebagai dasar untuk membuat keputusan kredit. Oleh karena itu, dalam penelitian ini pihak bank menjadi salah satu narasumber untuk mengidentifikasi kebutuhan informasi keuangan entitas mikro.

\section{Pengumpulan Data}

Strategi yang digunakan untuk mengumpulkan data primer dalam penelitian ini adalah dengan melakukan pengamatan langsung (direct observation) melalui teknik wawancara personal yang dilakukan dengan tatap muka langsung dengan responden (Hartono, 2012). Untuk mencapai tujuan penelitian ini, wawancara yang dilakukan merupakan wawancara mendalam (in depth interview) untuk mendapatkan informasi mendalam dari responden mengenai beberapa hal sebagai berikut.

1. Karakteristik entitas mikro di kota Yogyakarta

Untuk mendapatkan informasi mengenai karakteristik entitas mikro di kota Yogyakarta dilakukan wawancara mendalam dengan para pelaku dan pemilik entitas mikro. Informasi tersebut meliputi proses bisnis entitas mikro dan kapabilitas pengelola entitas (akses terhadap informasi, pendidikan, dan pengalaman).

2. Informasi keuangan yang dibutuhkan oleh pengguna laporan keuangan entitas mikro.

Kebutuhan informasi keuangan oleh pengguna laporan keuangan diperoleh dengan wawancara mendalam kepada pemilik atau pengelola entitas mikro dan pihak kreditur.

a. Wawancara mendalam kepada pemilik atau pengelola entitas mikro dilakukan untuk memperoleh informasi antara lain sebagai berikut.

i) Kebutuhan informasi keuangan dan peran laporan keuangan tersebut dalam pengambilan keputusan bisnis oleh pemilik atau pengelola entitas mikro.

ii) Pencatatan keuangan yang selama ini dilakukan oleh pengelola atau pemilik entitas.

iii) Pengetahuan pemilik atau pengelola mengenai SAK ETAP dan SAK EMKM. 
b. Wawancara mendalam kepada pihak kreditur dilakukan untuk mendapatkan informasi antara lain sebagai berikut.

i) Produk-produk yang disediakan oleh BRI untuk mendukung pembiayaan mikro.

ii) Kebutuhan informasi keuangan kreditur atas entitas mikro dalam hal pengambilan keputusan kredit.

iii) Cara yang dilakukan bank untuk mengatasi kesulitan dalam mendapatkan informasi keuangan dari entitas mikro.

Informasi diatas melalui wawancara mendalam yang dilakukan secara terstruktur dengan pertanyaan-pertanyaan terbuka. Pertanyaan terstruktur disusun berdasarkan kebutuhan informasi di atas dan juga diadaptasi dari kuesioner tertutup dari penelitian Rudiantoro (2011).

\section{Analisis Data}

Analisis data pada penelitian ini menggunakan metode deskriptif kualitatif, yaitu dengan mendeskripsikan secara menyeluruh data yang relevan selama proses penelitian. Data yang terkumpul dari wawancara kemudian diolah melalui beberapa tahap sebagai berikut menggunakan teknik analisis data dari Miles dan Hubberman. Tahapan tersebut antara lain sebagai berikut.

1. Melakukan reduksi data dari hasil wawancara.

Reduksi data dilakukan dengan mengurangi data yang dianggap tidak relevan dengan kebutuhan data. Reduksi data ini dilakukan dengan teknik pengkodean. Teknik pengkodean dilakukan dengan penomoran pada jawaban yang menjawab masingmasing pertanyaan.

2. Mengumpulkan data berdasarkan kategori kebutuhan data.

Data yang telah direduksi kemudian diklasifikasikan ke dalam pokok-pokok informasi yang dibutuhkan. Data yang telah diklasifikasikan tersebut yang nantinya akan dianalisis.

3. Melakukan analisis dengan intepretasi data. Analisis data dilakukan untuk menjawab pertanyaan penelitian dan mencapai tujuan penelitian. Analisis data yang dilakukan pada penelitian ini antara lain dengan analisis pemahaman makna untuk dapat melakukan identifikasi karakteristik entitas mikro di kota Yogyakarta dan identifikasi kebutuhan informasi keuangan oleh pengguna laporan keuangan entitas mikro. Selain itu dilakukan analisis pola dan hubungan untuk melakukan identifikasi penyajian informasi keuangan dan konsep standar akuntansi yang dapat memfasilitasi kebutuhan informasi keuangan entitas mikro serta untuk dapat menyimpulkan kesesuaian SAK EMKM dengan kebutuhan entitas mikro.

4. Menarik kesimpulan berdasarkan pada pola dan hubungan.

Pola dan hubungan dari data akan diperoleh dari hasil intepretasi. Berdasarkan pola dan hubungan data tersebut dapat ditarik kesimpulan untuk mengidentifikasi konsep standar akuntansi untuk entitas mikro dalam upaya memfasilitasi proses pencatatan dan penyajian laporan keuangan pada entitas mikro.

\section{HASIL PENELITIAN DAN PEMBAHASAN Responden Penelitian}

Responden pada penelitian ini terdiri dari pemilik dan pengelola entitas mikro di Kota Yogyakarta serta pihak kreditur dari Bank Rakyat Indonesia (BRI). Seluruh usaha mikro tersebut merupakan usaha yang dimililki oleh perseorangan dan pada umumnya pemilik juga merangkap sebagai pengelola. Responden selanjutnya adalah dari pihak BRI yang bank dengan fokus operasi yang diarahkan untuk memperluas akses pembiayaan dan perbankan kepada usaha mikro, kecil, dan menengah (UMKM). Pihak yang menjadi narasumber dari 
bank tersebut adalah petugas pada dua kantor cabang bank BRI.

Tabel 2. Daftar Responden Penelitian Entitas Mikro

\begin{tabular}{clcccc} 
No. & $\begin{array}{c}\text { Responde } \\
\mathbf{n}\end{array}$ & $\begin{array}{c}\text { Kod } \\
\mathbf{e}\end{array}$ & $\begin{array}{c}\text { Bidang } \\
\text { Usaha }\end{array}$ & Posisi & $\begin{array}{c}\text { Pendidikan } \\
\text { Terakhir }\end{array}$ \\
\hline 1. & Wayan I. & WI & $\begin{array}{c}\text { Dagang- } \\
\text { Retail }\end{array}$ & Pemilik & S2 \\
\hline 2. & $\begin{array}{l}\text { Wiwiek } \\
\text { S.R. }\end{array}$ & WS & $\begin{array}{c}\text { Dagang- } \\
\text { Batik }\end{array}$ & Pengelola & D3 \\
\hline 3. & Dewi Nur & DN & $\begin{array}{c}\text { Dagang- } \\
\text { Retail }\end{array}$ & Pengelola & D3 \\
\hline 4. & Sigit S. & SS & $\begin{array}{c}\text { Dagang- } \\
\text { Batik }\end{array}$ & Pemilik & SMA \\
\hline 5. & $\begin{array}{l}\text { H. } \\
\text { Yuniarto }\end{array}$ & HY & $\begin{array}{c}\text { Dagang- } \\
\text { Makanan }\end{array}$ & Pengelola & S1 \\
\hline 6. & Heru S & HS & $\begin{array}{c}\text { Dagang- } \\
\text { Batik }\end{array}$ & Pengelola & S1 \\
\hline
\end{tabular}

Tabel 3. Daftar Responden Penelitian dari Pihak Bank

\begin{tabular}{clll}
\hline No. & Responden & Cabang BRI & Posisi \\
\hline 1. & Anieta & $\begin{array}{l}\text { Sleman, } \\
\text { Yogyakarta }\end{array}$ & $\begin{array}{l}\text { Audit } \\
\text { Internal }\end{array}$ \\
\hline 2. & $\begin{array}{l}\text { Remirda Eva } \\
\text { Rosandi }\end{array}$ & $\begin{array}{l}\text { Bantaeng, } \\
\text { Sulawesi }\end{array}$ & $\begin{array}{l}\text { Audit } \\
\text { Internal }\end{array}$ \\
\hline
\end{tabular}

\section{Pemaparan Temuan}

Pada umumnya entitas mikro telah melakukan pencatatan keuangan untuk transaksi yang terjadi pada usahanya. Transaksi yang dicatat merupakan transaksi yang berkaitan langsung dengan arus masuk dan keluarnya kas usaha. Pada umumnya transaksi yang terjadi adalah transaksi pembelian persediaan barang dagang dan penjualan barang dagang. Selain itu, transaksi lainnya berkaitan dengan beban operasional usaha, seperti biaya beban listrik, beban gaji karyawan, dan beban lain-lain. Seluruh transaksi tersebut dicatat ketika arus kas masuk atau keluar akibat dari transaksi tersebut terjadi. Dengan demikian dapat dikatakan bahwa entitas mikro menerapkan dasar kas untuk pencatatan keuangannya.
Selain itu, entitas dagang mikro jarang memiliki transaksi yang ditangguhkan. Pendapatan diterima secara kas pada saat barang diserahkan. Transaksi tangguhan yang sering terjadi adalah hutang kepada pemasok. Pada umumnya pemasok menyerahkan persediaan barang dagang namun nilai barang tersebut dibayar setelah barang tersebut laku terjual. Namun, transaksi ini pada umumnya tidak dicatat untuk menjadi laporan keuangan. Transaksi tersebut akan dilaporkan ketika kas senilai barang tersebut dibayarkan kepada pemasok.

Kendala yang terjadi pada proses pencatatan tersebut adalah belum mampunya entitas mikro melakukan alokasi pembebanan yang tepat untuk usahanya. Sebagai contoh, untuk usaha yang lokasinya menjadi satu dengan rumah pemilik cenderung tidak melakukan pencatatan atas beban listrik karena biaya listrik tersebut telah dibayarkan sebagai keperluan rumah tangga.

Pencatatan yang dilakukan secara rutin merupakan pencatatan yang tujuannya digunakan untuk memenuhi kebutuhan informasi pemilik. Kebutuhan informasi keuangan pemilik tersebut antara satu entitas mikro dengan yang lainnya disesuaikan dengan karakteristik usaha dan pengetahuan pemilik. Dengan demikian tidak ada standar tertentu yang digunakan oleh entitas mikro untuk membuat laporan keuangannya.

lya yang penting tujuannya itu, kalau kami harus mengikuti standar akuntansi, kami malah ga jadi kerja. Biayanya banyak. Makanya kita membuat sistem sendiri yang intinya adalah gimana caranya menyediakan informasi untuk manajemen dan untuk evaluasi, tapi biayanya yang murah dan banyak yang bisa melakukannya. Gitu aja. (WI-26, Usaha Retail). 
Tabel 4. Pencatatan Keuangan oleh Entitas Mikro

\begin{tabular}{|c|c|c|}
\hline Responden & $\begin{array}{l}\text { Pencatatan } \\
\text { Keuangan }\end{array}$ & $\begin{array}{l}\text { Laporan } \\
\text { Keuangan }\end{array}$ \\
\hline WI & $\begin{array}{l}\text { Pencatatan } \\
\text { penjualan, } \\
\text { pembelian } \\
\text { barang } \\
\text { dagang, gaji } \\
\text { karyawan, } \\
\text { dan } \\
\text { pengeluaran } \\
\text { beban } \\
\text { harian. }\end{array}$ & $\begin{array}{l}\text { Laporan } \\
\text { kas } \\
\text { masuk } \\
\text { dan kas } \\
\text { keluar } \\
\text { bulanan. }\end{array}$ \\
\hline WS & $\begin{array}{l}\text { Pencatatan } \\
\text { penjualan } \\
\text { barang } \\
\text { dagang. }\end{array}$ & $\begin{array}{l}\text { Laporan } \\
\text { kas } \\
\text { harian. }\end{array}$ \\
\hline $\mathrm{DN}$ & $\begin{array}{l}\text { Pencatatan } \\
\text { penjualan } \\
\text { barang } \\
\text { dagang dan } \\
\text { beban- }\end{array}$ & $\begin{array}{l}\text { Laporan } \\
\text { kas } \\
\text { masuk } \\
\text { dan }\end{array}$ \\
\hline
\end{tabular}

Hasil temuan menunjukkan hal yang sama dengan beberapa penelitian terdahulu mengenai jenis pencatatan keuangan yang dilakukan oleh entitas mikro seperti penelitian Maseko (2011) di Zimbabwe yang menunjukkan bahwa UMKM pada sektor ritel membuat pencatatan keuangan berupa buku harian penjualan dan pembelian. Pada entitas dagang, beban tersebut berupa pembelian barang dagang dan beban operasional lainnya.

Pada entitas dagang, informasi hasil penjualan dapat membantu dalam pengambilan keputusan berkaitan dengan jumlah dan jenis barang yang laku terjual yang nantinya menjadi dasar untuk melakukan pembelian persediaan barang dagang.

Oh ya berpengaruh lah. Jadi misal ada barang yang masih banyak belum laku kita ga ambil lagi. Cuma ambil yang kayaknya laku. (WS-44, Usaha Dagang Batik)

Selain itu, dengan mencatat jumlah penjualan dan beban, pelaku usaha kecil dapat

\begin{tabular}{cll}
\hline Responden & $\begin{array}{l}\text { Pencatatan } \\
\text { Keuangan }\end{array}$ & $\begin{array}{l}\text { Laporan } \\
\text { Keuangan }\end{array}$ \\
\hline & $\begin{array}{l}\text { beban } \\
\text { setiap } \\
\text { bulan. }\end{array}$ & $\begin{array}{l}\text { keluar } \\
\text { bulanan. }\end{array}$ \\
\hline SS & $\begin{array}{l}\text { Pencatatan } \\
\text { penjualan } \\
\text { barang } \\
\text { dagang. }\end{array}$ & $\begin{array}{l}\text { Tidak } \\
\text { membuat } \\
\text { laporan. }\end{array}$ \\
\hline HY & $\begin{array}{l}\text { Pencatatan } \\
\text { penjualan }\end{array}$ & Laporan \\
& kas \\
& dagang & masuk \\
& bebang, & dan \\
& keluar, \\
& keban & harian \\
harian, dan & untuk \\
beban & bagi hasil. \\
& lainnya. & \\
\hline HS & $\begin{array}{l}\text { Pencatatan } \\
\text { penjualan } \\
\text { barang } \\
\text { dagang. }\end{array}$ & $\begin{array}{l}\text { Laporan } \\
\text { kas } \\
\text { masuk }\end{array}$ \\
& harian. \\
\hline
\end{tabular}

menghitung laba atau rugi usahanya melalui selisih jumlah penjualan dan beban usaha.

Sudah dari tahun 1998 sih iya mbak. Kan kita bisa tau margin, biaya kita tau, sehingga bisa tau laba sebelum pajak. Ya setidaknya dari situ bisa dibuat keputusan. (WI-50, Usaha Retail)

Entitas kecil cenderung memiliki modal yang rendah sehingga bergantung pada ketersediaan kas untuk beroperasi. Oleh karena itu pencatatan dengan dasar kas dianggap mudah dan lebih menunjukkan nilai arus kas yang lebih handal. Temuan ini mendukung penelitian Maseko (2011) dan Amoah (2012) yang menunjukkan bahwa entitas kecil telah mampu membuat catatan melaui kas dan sebagian kecil membuat catatan akrual.

Entitas mikro belum mampu membuat pencatatan untuk akun-akun di dalam laporan posisi keuangan yang cenderung berbasis akrual. Laporan untuk aset khususnya aset tetap, kewajiban, dan modal dianggap belum 
memberikan informasi yang berguna bagi keputusan bisnis mereka. Walaupun ada yang beranggapan apabila informasi tersebut tersedia akan dapat membantu pengambilan keputusan yang lebih baik.

\section{Pembahasan}

Karakteristik Entitas Mikro di Kota Yogyakarta

Dari hasil penelitian ditemukan bahwa entitas mikro di kota Yogyakarta dalam bidang perdagangan pada umumnya memiliki karakteristik yang sama dengan entitas mikro di Asia seperti yang dikemukakan oleh Tambunan (2009). Usaha-usaha tersebut merupakan usaha perseorangan yang dikelola dan dijalankan oleh keluarga dengan sistem kepercayaan. Hal ini seperti yang disampaikan oleh Akyuwen (2010) bahwa usaha mikro memiliki tendensi untuk menjadi bagian dari jaringan keluarga atau unit rumah tangga yang lebih besar.

Pada jenis entitas ini, pemilik juga merupakan pengelola usaha yang secara personal terlibat dalam manajemen. Dengan demikian pada entitas mikro kecenderungan adanya konflik keagenan sangat rendah dibandingkan dengan entitas yang lebih besar dengan struktur kepemilikan yang lebih kompleks. Pada entitas mikro pemilik yang sekaligus pengelola memiliki kendali langsung terhadap keputusan manajemen. Berbeda dengan entitas dengan struktur kepemilikan yang lebih kompleks, konflik keagenan antara manajemen dan pemilik akan cenderung lebih tinggi akibat dari tingginya asimetri informasi.

Karakter entitas mikro yang pada umumnya dimiliki oleh perseorangan menunjukkan bahwa entitas mikro memiliki struktur modal yang sederhana. Modal awal usaha berasal dari setoran modal pemilik atau berasal dari modal sendiri. Pemilik memiliki kewajiban yang tidak terbatas atas usaha tersebut sehingga seluruh kewajiban (hutang) usaha menjadi tanggung jawab pemilik. Oleh karena itu, pemilik ataupun pengelola entitas pada sektor mikro cenderung sangat berhatihati dalam melakukan pengajuan kredit.
Beberapa pemilik usaha yang tidak berani mengambil resiko cenderung akan menghindari penggunaan modal dari kredit.

Proses produksi pada entitas mikro pada umumnya cukup sederhana dan cenderung dengan penggunaan teknologi yang rendah. Selain itu, pada umumnya entitas mikro cenderung belum menggunakan teknologi sistem informasi untuk mendukung operasi usahanya. Rendahnya penggunaan teknologi informasi atau justru belum digunakannya teknologi informasi cenderung memperlambat pengambilan keputusan usaha.

Menurut Tambunan (2009), salah satu karakteristik entitas mikro adalah pemilik yang tidak memiliki pendidikan tinggi. Namun demikian, karakteristik tersebut tidak lagi sesuai dengan kondisi saat ini. Hal ini karena dengan semakin gencarnya program pemerintah yang menggencarkan pertumbuhan kewirausahaan dan semakin tingginya kesadaran para pemuda untuk membuka lowongan pekerjaan baru mendorong para pemuda baik yang berpendidikan tinggi maupun tidak untuk membuka usaha. Dengan demikian, entitas mikro tidak lagi identik dengan pemilik atau pengelola yang tidak berpendidikan tinggi.

Namun demikian, para pemilik maupun pengelola entitas mikro masih memiliki pengetahuan yang sederhana mengenai pencatatan informasi keuangan. Pada umumnya entitas mikro telah membuat pencatatan dan laporan keuangan berdasarkan kebutuhan pribadi pemilik dan belum mampu menyajikannya untuk pihak eksternal.

\section{Pemilik dan Kebutuhan Informasi Keuangan}

Pemilik merupakan pihak yang paling banyak menggunakan informasi yang ada pada laporan keuangan karena berkaitan dengan pengambilan keputusan operasional bisnis. Selain itu, manajemen akan membuat laporan keuangan untuk pihak kreditur yang dalam hal ini adalah bank, hanya saat pemilik akan mengajukan kredit. Pemilik membutuhkan laporan keuangan sebagai dasar pengambilan 
keputusan bisnis. Fungsi laporan keuangan untuk dapat mengurangi asimetri informasi antara principal dan agen, tidak relevan pada entitas mikro. Pada entitas mikro cenderung tidak terjadi konflik keagenan yang muncul akibat asimetri informasi antara principal dan agen. Hal ini sesuai dengan karakteristik entitas mikro yang pada umumnya dimiliki oleh perseorangan dan pada entitas ini pemilik juga merangkap sebagai manajer pengelola. Laporan keuangan pada kondisi ini bukan merupakan suatu bentuk pertanggungjawaban dari manajemen kepada pemilik namun lebih sebagai alat dalam mengelola bisnis.

Penggunaan laporan keuangan untuk mengelola bisnis terwujud dari digunakannya laporan keuangan sebagai dasar pengambilan keputusan bisnis. Pengambilan keputusan bisnis pada entitas mikro cenderung bersifat operasional dengan periode yang pendek, misalnya harian dan bulanan. Oleh karena itu, laporan keuangan entitas mikro juga cenderung memiliki periode yang pendek dan berbeda-beda antara entitas satu dan lainnya. Dengan kata lain dapat disebutkan bahwa pada entitas mikro dibutuhkan standar akuntansi yang berbeda berdasarkan pada ukuran dan karakteristik kepemilikan usaha.

Untuk memenuhi kebutuhan pengambilan keputusan secara operasional tersebut, para pelaku entitas mikro membutuhkan informasi keuangan yang berkaitan dengan penerimaan dan pengeluaran kas secara harian maupun bulanan. Berdasarkan hasil temuan menunjukkan bahwa informasi penerimaan dan pengeluaran kas tersebut dilakukan dengan dasar kas, yaitu transaksi akan dicatat ketika ada aliran kas masuk maupun keluar. Hal ini menunjukkan bahwa pemilik entitas mikro cenderung membutuhkan informasi yang berkaitan dengan kas yang dimiliki usahanya.

Entitas mikro akan bergantung pada arus kas usahanya untuk dapat beroperasi. Oleh karena itu,pada entitas mikro informasi arus kas menjadi standar ukuran keuangan yang tajam dan jelas. Selain itu menurut Stockstill et. Al (1989) informasi arus kas tersebut mengukur likuiditas jangka panjang dan dapat digunakan untuk memprediksikan solvabilitas jangkan panjang.

Informasi arus kas tersebut juga lebih mudah untuk dibuat dan dipahami oleh pemilik. Informasi arus kas juga dianggap lebih relevan karena pada entitas mikro jarang ada transaksi-transaksi yang bersifat akrual. Dengan memahami perubahan dalam kas selama suatu periode dapat memberikan manfaat bagi manajemen yaitu saldo kas dapat memberi sinyal bahwa pendapatan dan kas tidak menunjukkan nilai yang sama. Dari informasi arus kas juga menunjukkan bahwa arus kas keluar dan arus kas masuk yang utama terkadang bukan dari aktivitas non operasional. Dengan demikian, informasi arus kas dapat memberikan dasar untuk pengambilan keputusan baik dalam hal keputusan untuk bertumbuh maupun untuk evaluasi (Stockstill et al., 1989).

\section{Kreditur dan Kebutuhan Informasi Keuangan}

Pada penelitian ini pihak kreditur merupakan pihak bank yang memiliki fokus operasi yang diarahkan untuk memperluas akses pembiayaan dan perbankan pada usaha mikro, kecil, dan menengah. Dari hasil wawancara menunjukkan bahwa pada dasarnya pihak bank sangat membutuhkan informasi keuangan dari debitur (entitas usaha). Bank mensyaratkan suatu usaha untuk dapat memiliki prospek atau dapat dinilai dari kemampuan suatu usaha menghasilkan keuntungan selama 6 (enam bulan) atau dapat dikatakan sudah memiliki prospek dan sudah untung meskipun belum bankable (B-A1, Audit Internal BRI).Untuk memperoleh informasi tersebut pada umumnya bank membutuhkan informasi laba atau rugi usaha selama 6 (enam) bulan.

Hal ini menunjukkan bahwa pihak bank membutuhkan informasi yang berkaitan dengan pendapatan dan beban usaha mikro. 
Dari informasi tersebut dapat diproyeksikan prospek usaha dari klien yang mengajukan kredit yang berhubungan dengan kemampuan pelunasan kredit oleh klien (debitur). Hal ini berdasarkan pada pernyataan dari pihak BRI. ........... Lha itu, dia cuma tanya, ibu omzetnya berapa kira-kira sebulan berapa? Trus misalnya dia usahanya apa, perdagangan nah itu ditanyain bahan baku berapa harganya. Oh margin saya biasanya cuma $10 \%$ mas terus dikira-kira. Gitu aja. Kalau nanti dia (debitur) punya catetannya itu yang dijadikan dasar tapi tidak wajib kalau mikro. (B-R12, Audit Internal BRI).

Pihak bank juga menyatakan bahwa informasi di dalam neraca seperti informasi aset tetap tidak menjadi pertimbangan utama pihak bank. Hal ini seperti yang disampaikan oleh pihak BRI sebagai berikut.

Kalau agunan itu ga sampai sih liat neraca. Jadi kalau misalnya usahanya dinilai bagus dan dia (debitur) cuma punya BPKB motor, misalnya motor bebek gitu. Bisa kok dikasih seratus juta. Jadi kalau masalah pinjaman kenapa kok kita sampai berani tidak memberikan agunan karena $70 \%$ diklaim asuransi Askrindo karena kan program pemerintah kan. Jadi kita cuma menanggung aja rugi 30\%. (B-R48, Audit Internal BRI).

Informasi keuangan terkait hal tersebut diperoleh tidak hanya didapat berdasarkan pengakuan dari debitur, namun pihak BRI sendiri juga melakukan analisis terhadap usaha tersebut, termasuk dalam hal laporan keuangan. Pihak BRI akan melakukan recasting terhadap laporan keuangan yang dibuat calon debitur. Untuk entitas mikro, laporan keuangan merupakan salah satu komponen dalam membuat keputusan kredit, terdapat indikator non finansial lain yang dianggap lebih penting, seperti hubungan antara bank dengan debitur (klien) dan rekam jejak dari klien. Seperti yang disampaikan oleh Kirsch dan Meth (2007), pada smaller-small medium enterprises (SMEs) atau disebut entitas mikro pihak bank tidak mendasarkan keputusannya pada laporan keuangan yang dipublikasikan. Hal tersebut karena mereka memiliki kemampuan untuk meminta dan mengumpulkan informasi keuangan yang dibutuhkan.

Hal ini khusus dilakukan pada entitas mikro karena mempertimbangkan karakteristik dari entitas mikro yang pada umumnya memiliki keterbatasan dalam membuat catatan keuangan. Seringkali pihak bank juga membantu debitur untuk menyusun laporan keuangan. Mayoritas debitur tidak memiliki laporan keuangan sendiri namun menyimpan pencatatan keuangan secara sederhana. Beberapa debitur bahkan tidak memiliki catatan keuangan sama sekali sehingga pihak bank harus secara detail melakukan perhitungan terhadap aspek aspek usaha debitur (kas, persediaan, piutang, hutang, dan lainnya).

Bagi debitur yang sudah memiliki pencatatan keuangan, pihak bank akan membantu menyusunnya dalam bentuk laporan keuangan sekaligus melakukan cross check terhadap catatan tersebut. Pihak debitur harus mengetahui hasil neraca \& laba/rugi tersebut dan menyetujui bentuk laporan tersebut secara tertulis dalam bentuk tandatangan.

Kalau nanti dia (debitur) punya, catatannya itu yang dijadikan dasar tapi tidak wajib kalau mikro. Itu saja nilai repayment capacity- nya tidak harus dikasih tau ke debitur. Kecuali kalau di cabang kan gede kan ratail, itu debiturnya harus tanda tangan di laporan keuangan yang dibikinkan oleh mantrinya. (B-R12, Audit Internal BRI)

Pada umumnya untuk usaha mikro pihak bank telah melakukan pendekatan dan pendampingan usaha sehingga informasi yang disampaikan oleh debitur diharapkan merupakan informasi yang valid. Hal ini seperti yang telah disampaikan sebelumnya bahwa 
hubungan antara bank danklien (debitur) merupakan salah satu indikator dalam pembuatan keputusan kredit usaha mikro.

Pihak Bank Rakyat Indonesia juga menyatakan bahwa dengan adanya program pendampingan usaha, antara pihak klien (entitas mikro) dan pihak bank akan memiliki hubungan yang kuat. Hal ini akan meningkatkan kepercayaan dan kualitas penilaian bank pada klien. Selain itu, dengan kepemilikan perseorangan, pemilik usaha akan memiliki kewajiban yang tak terbatas atas hutang-hutang usaha. Hal ini juga menjadi sebuah jaminan bagi bank dalam memberikan kredit pada entitas mikro.

\section{Konsep Standar Akuntansi dan Penyajian Informasi Keuangan Entitas Mikro}

Neag (2009) bahwa penting untuk memahami kebutuhan informasi yang khusus dari entitas mikro maka perlu dilakukan identifikasi terhadap karakterisik usaha dari entitas mikro dan kebutuhan informasi keuangan pengguna laporan keuangan entitas mikro. Bagi entitas mikro konsep standar yang dibutuhkan adalah konsep standar tertentu yang cenderung sederhana. Hal ini seperti yang disampaikan oleh Wyk (2009) IFRS for SME saja masih terlalu besar dan jauh dari sederhana bila diterapkan pada entitas kecil dan menengah. Apalagi bila standar tersebut diterapkan pada entitas mikro yang merupakan entitas bisnis dengan tipe transaksi yang paling sederhana. Selanjutnya, pada penelitian Wyk (2009) menunjukkan bahwa diatas $70 \%$ responden setuju adanya standar sendiri untuk entitas mikro di Afrika. Negara-negara Eropa (European Union) juga telah mengusulkan untuk dapat mengurangi beban regulasi untuk bisnis-bisnis kecil.

Contract partner merupakan pihak-pihak yang memiliki kontrak kepentingan dengan suatu entitas. Jumlah contract partner dapat diidentifikasi melalui karakteristik kualitatif entiats, yaitu dari struktur kepemilikan dan sumber modalnya serta dari proses produksi dan orientasi pasar usaha.

Entitas mikro memiliki contract partner yang cenderung lebih sedikit dari entitas lain yang lebih besar. Hal ini menunjukkan bahwa entitas mikro menyajikan laporan keuangan untuk sekelompok kecil pengguna. Sesuai dengan karakteristik entitas mikro yang cenderung memiliki modal terbatas akan berfokus pada arus kas masuk dan arus kas keluar usahanya dalam jangka pendek. Hal ini bertujuan untuk membuat keputusan bisnis yang sifatnya operasional. Perhitungan laba atau rugi usaha diperoleh dari selisih arus kas masuk dan keluar.

Entitas mikro pada umumnya memiliki proses produksi yang sangat sederhana sehingga jenis dan jumlah transaksi bisnisnya cenderung tidak beragam. Transaksi yang terjadi pada umumnya bersifat kas dan jarang terjadi transaksi akrual, khususnya pada sektor perdagangan. Selain itu, entitas mikro merupakan entitas yang memiliki jumlah aset tetap yang tidak material. Kondisi ini tidak mengharuskan entitas mikro untuk melakukan pengungkapan yang kompleks pada laporan keuangannya.

Selain itu, pihak kreditur lebih membutuhkan informasi yang menunjukkan kinerja suatu entitas. Hal ini berkaitan dengan penilaian kemampuan entitas untuk melunasi hutangnya. Untuk mempermudah dalam perolehan informasi keuangan, pihak bank menghendaki perhitungan kemampuan entitas mikro untuk menghasilkan laba melalui perhitungan jumlah arus kas masuk dan keluar. Arus kas masuk dinilai dari jumlah rupiah pendapatan yang diperoleh dan arus kas keluar merupakan beban-beban yang dibayarkan selama beroperasi.

Dari penjelasan di atas, dapat diusulkan penggunaan dasar akuntansi kas untuk entitas mikro. Dengan demikian pendapatan dan beban akan diakui pada saat kas diterima atau dibayarkan. Penggunaan dasar kas ini akan memberikan pilihan yang lebih mudah untuk 
entitas mikro agar dapat menyajikan laporan keuangan. Selain itu, pihak bank juga menyadari rendahnya kapabilitas dari entitas mikro untuk mampu menyajikan laporan keuangan dengan dasar akrual. Pihak bank menganggap penyajian laporan keuangan dengan dasar kas dapat memenuhi kebutuhan informasi keuangan mereka terhadap entitas mikro.

Namun demikian dengan memperhatikan karakteristik dan kebutuhan pengguna pada entitas mikro, dasar kas akan lebih membantu entitas mikro untuk membuat laporan laba rugi dengan lebih mudah dan andal. Dalam Standar Akuntansi Keuangan Entitas tanpa Akuntabilitas Publik (SAK ETAP) disebutkan bahwa dalam pengakuan unsur dalam laporan keuangan harus memiliki kemungkinan bahwa manfaat ekonomi yang terkait dengan pos tersebut akan mengalir dari atau ke dalam entitas dan pos tersebut memiliki nilai yang diukur secara diukur secara andal. Dengan dasar kas entitas tidak perlu lagi menganalisis probabilitas manfaat ekonomi masa depan suatu pos dalam laporan keuangan. Nilai atau biaya dengan dasar kas dapat diukur secara andal walaupun cenderung kurang relevan bila dibandingkan dengan dasar akrual.

Entitas dapat saja mengakui sewa dibayar di muka yang terlalu besar pada satu periode dan terlalu kecil pada periode selanjutnya. Namun, kembali lagi pada karakteritik entitas mikro yang tergantung pada kecukupan kas untuk kebutuhan operasionalnya. Entitas mikro cenderung membutuhkan informasi faktual mengenai ketersediaan kasnya. Selain itu, misalnya untuk akumulasi penyusutan yang merupakan alokasi nilai aset tetap pada setiap periode yang tidak berhubungan dengan arus masuk atau keluar kas merupakan informasi yang tidak dibutuhkan oleh entitas mikro. Untuk mengatasi berkurangnya masa manfaat aset atau untuk mempersiapkan penggantian atau perbaikan suatu aset tetap entitas mikro dapat membuat catatan atau pengungkapan pada laporan keuangan sebagai bagian terpisah dari laporan keuangan.

European Commission dalam Final Report of The Expert Group Accounting Systems For Small EnterprisesRecommendations And Good Practices menyatakan bahwa dalam hal entitas bisnis merupakan bisnis mikro atau bahkan bisnis yang sangat kecil dapat lebih cocok menggunakan dasar akuntansi kas. Beberapa negara di Eropa menggunakan dasar kas sebagai dasar pembuatan laporan keuangan untuk perpajakan dan beberapa laporan eksternal lainnya. Namun, seperti yang telah dibahas bahwa dasar akrual dapat memberikan gambaran posisi keuangan yang lebih nyata, maka dapat diusulkan bahwa untuk entitas mikro dapat memilih antara dasar akuntansi kas atau akrual.

Dalam mendukung penyederhanaan laporan keuangan bagi entitas mikro, laporan keuangan yang perlu disajikan oleh entitas mikro adalah laporan laba rugi dan laporan posisi keuangan. Untuk laporan keuangan lainnya, yaitu laporan perubahan ekuitas, laporan arus kas, dan catatan atas laporan keuangan dianggap tidak memberikan manfaat dalam pengambilan keputusan pada sektor mikro. Selain itu, para pihak pengguna juga tidak mensyaratkan adanya ketiga laporan tersebut. Hal ini didasarkan pada hasil analisis pola dan hubungan dari kebutuhan informasi dari pengguna laporan keuangan.

Pemiliki atau pengelola dan kreditur lebih berfokus untuk menilai kemmapuan entitas untuk menghasilkan kas dan laba. Dalam hal ini, laporan keuangan yang dapat memenuhi kebutuhan tersebut adalah laporan laba rugi yang pengakuan transaksinya berdasarkan kas. Hal ini sesuai dengan yang disampaikan oleh United Nation Conference on 
Trade and Development (UNCTAD) ${ }^{2}$ yang menyebutkan bahwa entitas pada level 3 (entitas terkecil yang dimiliki dan dikelola perseorangan) sebaiknya membuat laporan keuangan berupa laporan posisi keuangan dan laporan laba rugi yang lebih sederhana.

Hal yang sama juga dilakukan oleh Pemerintah Inggris dengan memberikan keleluasaan yang berkaitan dengan publikasi laporan keuangan tahunan bagi bisnis dengan skala yang lebih kecil. Hal ini bertujuan untuk memberikan kesempatan bagi entitas mikro untuk dapat menyajikan dan mempublikasikan laporan keuangan yang lebih sederhana ${ }^{3}$. Laporan keuangan yang dimaksud dalam hal ini adalah laporan laba/rugi dan laporan posisi keuangan. Keleluasaan yang ditawarkan oleh Pemerintah Inggris adalah entitas mikro hanya perlu untuk membuat laporan posisi keuangan dan laporan laba/rugi yang lebih ringkas. Senada yang disampaikan oleh Pacter (2008) bahwa laporan keuangan yang dibutuhkan adalah dua laporan utama yaitu laporan laba/rugi dan laporan posisi keuangan dengan pengungkapan yang sederhana.

Hal tersebut juga didukung oleh pernyataan dari pihak bank yang menjadi responden penelitian bahwasannya pihak bank lebih membutuhkan informasi untuk dapat menilai kemampuan entitas mikro dalam menghasilkan kas. Selain itu juga informasi yang berkaitan dengan beban-beban dan pengeluaran yang menjadi kewajiban entitas. Lebih lanjut pihak bank menyampaikan bahwa saat ini program untuk entitas mikro dengan rentang pinjaman tertentu tidak membutuhkan agunan. Dengan demikian,

\footnotetext{
2 UUNCTAD merupakan organisasi internasional dan organ utama majelis umum PBB yang menangani isu perdagangan, investasi, dan pembangunan. UNCTAD memiliki International Strandard of Accounting and Reporting yang memiliki produk berupa Accounting and Financial Reporting Guidelines for Small and Medium-Sized Enterprises (SMEGA)
}

informasi yang berkaitan dengan aset entitas pada umumnya tidak diperlukan.

Makanya kalau kreditur butuhnya laba rugi. Penting banget itu. Manfaatnya besar laporan laba rugi kan. Untuk penilaian kemampuan kinerja entitas biar mantrinya ga pake perkiraan dan bisa dipertanggungjawabkan laporannya. (BR52 \& B-R54, Audit Internal BRI)

Laporan laba rugi akan memberikan informasi mengenai kemampuan entitas bisnis dalam menghasilkan laba, yang menjadi ukuran kinerja entitas. Pemilik dapat memperoleh informasi sebagai dasar pengendalian dan evaluasi kinerja. Pada pihak kreditur, informasi kinerja merupakan informasi yang dijadikan dasar untuk membuat keputusan kredit. Informasi ini digunakan untuk menilai kemampuan perusahaan selama periode tertentu sesuai dengan standar dari bank. Misalnya, pada Bank Rakyat Indonesia, suatu entitas dianggap feasible ketika telah mampu menghasilkan laba selama 6 bulan sejak berdirinya.Selain itu, laporan posisi keuangan suatu entitas dapat memberikan informasi mengenai posisi aset, kewajiban, dan ekuitas suatu entitas pada suatu tanggal tertentu.

Untuk menyusun laporan keuangan tersebut, pencatatan keuangan yang perlu dilakukan oleh entitas dagang mikro berupa buku penjualan harian, buku pembelian harian, buku penerimaan kas harian, buku pembayaran harian, daftar aset. Pencatatan harian ini digunakan untuk meningkatkan akurasi dan reliabilitas dari transaksi akuntansi.Dalam proses pencatatan transaksi keuangan, perlu adanya konsep pencatatan

3 5Pernyataan ini merupakan respon dari pemerintah Inggris dalam artikel 'Simpler Financial Reporting for Micro Entities: The UK's Proposal to Implement the 'Micros Directive' (September 2013) untuk memberikan keleluasaan untuk entitas mikro dan secara penuh mendukung usaha untuk mengurangi beban pada entitas mikro 
akuntansi berganda (double-entry bookkeeping), yaitu setiap transaksi yang dicatat mempengaruhi setidak-tidaknya dua akun. Misalnya terjadi penjualan barang dagangan maka transaksi tersebut akan mempengaruhi akun kas atau piutang dan penjualan. Penyajian laporan keuangan oleh entitas mikro tetap harus memenuhi prinsip penyajian wajar yang mensyaratkan adanya penyajian jujur atas pengaruh transaksi, peristiwa, dan kondisi lain.

Laporan keuangan entitas harus dilakukan minimal satu kali dalam satu tahun. Apabila terdapat perbedaan periode pencatatan menjadi lebih pendek atau lebih panjang maka entitas harus melakukan pengungkapan. Hal ini berkaitan dengan prinsip konsistensi dalam pelaporan keuangan yang mensyaratkan konsistensi penyajian dan klasifikasi pos-pos dalam laporan keuangan antar periode. Dengan demikian, informasi dalam laporan keuangan dapat diperbandingkan antar periode.

Standar untuk Entitas Mikro Kecil dan Menengah (EMKM) telah berusaha mengakomodir konsep standar yang dibutuhkan oleh entias mikro dengan menyederhanakan konsep yang ada pada SAK ETAP. Salah satunya adalah dengan mengurangi laporan yang dibuat oleh pelaku usaha. Laporan tersebut adalah laporan laba rugi, laporan posisi keuangan, dan catatan laporan keuangan. Namun demikian, asumsi yang digunakan masih asumsi dengan dasar akrual.

Beberapa penelitian masih menunjukkan rendahnya pemahaman pelaku usaha mikro dalam mengimplementasikan standar tersebut. Salah satunya adalah penelitian Salmiah (2018) yang menunjukkan bahwa pemahaman pelaku UMKM mengenai asumsi dasar akrual masih cukup rendah. Hal ini masih mendukung penelitian terdahulu yang menunjukkan bahwa pelaku usaha mikro cenderung lebih mudah menggunakan dasar kas disbanding dengan dasar akrual. Selain itu untuk pemahaman mengenai pengukuran dengan dasar historis dan mengenai penyajian laporan keuangan menunjukkan nilai yang cukup tinggi.

\section{PENUTUP}

\section{Kesimpulan}

Dari hasil penelitian dapat disimpulkan hasil penelitian sebagai berikut.

1. Entitas mikro memiliki karakteristik antara lain, memliki jumlah contract partner yang sedikit (umumnya pemilik, pihak bank, dan pemerintah), transaksi bisnis yang sederhana, serta rendahnya pengetahuan pemilik mengenai penyajian laporan keuangan untuk pihak luar.

2. Pengguna laporan keuangan dalam penelitian ini berfokus pada pemilik dan kreditur sebagai pihak yang berkontribusi untuk memberikan tambahan modal.

a. Pemilik menggunakan laporan keuangan sebagai alat pengambilan keputusan operasional sehingga informasi yang dibutuhkan adalah informasi dengan frekuensi yang pendek. Untuk memenuhi tujuan tersebut pada umumnya informasi yang dibutuhkan adalah informasi arus kas masuk dan keluar yang dicatat berdasarkan transaksi pembelian persediaan barang dagang dan penjualan barang dagang.

b. Kreditur membutuhkan informasi keuangan sebagai dasar dalam pembuatan keputusan kredit. Kreditur membutuhkan informasi yang berkaitan dengan kinerja entitas mikro. Informasi kinerja tersebut berasal dari pendapatan yang diterima dan beban yang harus dikeluarkan pada periode tertentu.

3. Konsep standar dan penyajian laporan keuangan entitas mikro yaitu sebagai berikut.

a. Konsep standar yang dibutuhkan oleh entitas mikro, yaitu asumsi dasar pengakuan transaksi menggunakan dasar kas. Dalam hal ini, penggunaan dasar kas bertujuan untuk mempermudah entitas mikro untuk 
melakukan pencatatan selain dengan dasar kas informasi yang dihasilkan akan lebih memenuhi kebutuhan pemilik. Namun demikian, untuk menghasilkan informasi keuangan yang lebih andal dan relevan, entitas mikro dapat menggunakan dasar akrual dalam mengakui transaksi bisnisnya. Selain itu, dasar pengukuran transaksi tersebut dapat menggunakan biaya historis, yaitu sebesar nilai wajar saat perolehan. Selain itu, konsep lainnya yang perlu diterapkan adalah konsep kelangsungan usaha dan konsep entitas bisnis.

b. Entitas mikro hanya perlu membuat dua laporan keuangan utama, yaitu laporan laba rugi dan laporan posisi keuangan. Hal ini disesuaikan dengan kebutuhan informasi dari para pengguna laporan keuangan. Kedua laporan keuangan tersebut merupakan informasi minimal yang perlu disajikan oleh entitas mikro. Dalam penyajiannya entitas mikro perlu untuk memperhatikan konsistensi dalam penyajian sehingga dapat diperbandingkan.

4. Konsep standar yang diusulkan tersebut salah satunya telah terimplemntasi pada SAK EMKM, yaitu penyederhanaan jumlah laporan keuangan yang wajib dibuat oleh entitas mikro yang hanya terdiri dari laporan laba rugi, laporan posisi keuangan, dan catatan atas laporan keuangan.

\section{Keterbatasan}

1. Penelitian ini hanya berfokus pada entitas mikro dalam industri perdagangan.

2. Penelitian ini hanya di lakukan di kota Yogyakarta.

\section{Saran}

1. Penelitian selanjutnya dapat menambahkan objek penelitian pada jenis industri lainnya, yaitu pada sektor jasa dan manufaktur.

2. Penelitian selanjutnya dapat memperluas penelitian pada daerah lain di Indonesia.

\section{DAFTAR PUSTAKA}

Akyuwen, R, et al. (2010). Teori dan Praktek Keuangan Mikro di Indonesia. Yogyakarta: Sekolah Pasca Sarjana Universitas Gajah Mada.

Amoah, R., \& Samuel, N. (2014). Accounting Practices of SMES In Sunyani : An Investigative Study of Record Keeping For Performance Measurement. International Journal of Research in Economics \& Social Sciences, 4(7), 2135.

Amoako, G. K. (2013). Accounting Practices of SMEs: A Case Study of Kumasi Metropolis in Ghana. International Journal of Business and Management, 8(24), 73-83.

European Commission. (2008). Final Report of the Expert Group-Accounting Systems for Small Enterprises-Recommendation and Good Practice. Directorate-General for Enterprise and Industry.

Fulbier, Rofl Uwe., \& Gassen Joachim. (2010). IFRS for European Small and MediumSized Entities? A Theoretical and Empirical Analysis. Research Report commissioned by Deutscher Genossenschafts-und raiffeisenverband e. V.

Hartono, Jogiyanto. (2012). Metodologi Penelitian Bisnis - Salah Kaprah dan Pengalaman-pengalaman. Yogyakarta : BPFE.

International Labour Organisation (ILO, 1997), General Conditions to Stimulate Job Creation in Small and Medium-Size Enterprises, Report of an International Labour Organisation conference, 85th session, Geneva.

International federation of Accountants. (2006). Micro-Entity Financial Reporting: Perspectives of Preparers and Users. Small and Medium Practices Committee, Information Paper.

Kementrian Koperasi dan UKM. (2010). Perkembangan Data Usaha Mikro, Kecil, 
Menengah (UMKM) Dan Usaha Besar ( $U b=)$.

Stockstill, Lowell E., et al. (1983). A Cash Flow Focus for Small Business. Journal of Business and Entrepreneurship, Oct 1989; 1,2; ABI/INFORM Complete pg 45.

Maseko, N. (2011). Accounting practices of SMEs in Zimbabwe: An investigative study of record keeping for performance measurement (A case study of Bindura). Journal of Accounting and Taxation, 3(8), 171-181.

Mawardi, Kholid M. (2014). The Survival of Micro, Small, and Medium Enterprises (MSMEs) in Indonesian Industrial Clusters: A Case Study of the Furniture and Footwear Industrial Cluster of East Java Province, Indonesia. University of Wollongong Thesis Collection: University of Wollongong Research Online.

Mbroh, John Kwaning \& Ben Ebo Attom. (2011). Accounting and Control Systems Practiced By Small and Micro Enterprise Owners within the Cape Coast Metropolitan Area of Ghana. Asian Journal of Business and Management Sciences Vol. 1 No. 9 (28-47).

Miles, Mattew B \& Huberman, A.Michael. Qualitative Data Analysis.Second Edition. London: SAGE Publications.

Nair, R. D. and L. E. Rittenberg. (1983). Alternative Accounting Principles for Smaller Business : Proposals and Analysis. Journal of Commercial Bank Lending 65, pp: 2-21.

Neag, Ramona, E. M. and I. P. (2009). Actual Aspects Regardind the Ifrs for Sme Opinions, Debates and Future Developments. Annales Universitatis Apulensis Series Oeconomica, 11(1), pp: 32-42.

Neag, Ramona and Masca Ema. (2012). Determinants In Accounting Regulation for Micro-Entities-a Romanian Perspective. Procedia Economics and Finance 3 (2012) pp: 223-229.
Rudiantoro, Rizki \& Siregar, S. V. (2011). Kualitas Laporan Keuangan UMKM Serta Prospek Implementasi SAK ETAP. Simposium Nasional Akuntansi XIV Aceh 2011, pp: 21-22.

Ikatan Akuntan Indonesia. (2013). Standar Akuntansi Entitas tanpa Akuntabilitas Publik.

Salmiah, Neneng., Tri Nanda, Satria., \& Intan Adinno. (2018). Pemahaman Pelaku UMKM Terhadap SAK EMKM pada UMKM yang Terdaftar di Dinas Koperasi Kota Pekanbaru. Jurnal Akuntansi Dewantara Vol.2 No. 2.

Stockstill, Lowell E., Dietz Sharon L., \& Maurer, Wayne O. (1989). A Cash Flow Focus for Small Business. Journal of Business and Entrepreneurship; Oct 1989; 1,2; ABI/INFORM Complete pg. 45.

Suthapa, I Dewa Gde, (2008). Optimalisasi Peran Bank Perkreditan Rakyat Dalam Penanggulangan Kemiskinan di Provinsi Jawa Barat. Disertasi, tidak dipublikasikan. Yogyakarta: Sekolah Pascasarjana Universitas Gadjah Mada.

Standar Akuntansi Entitas Tanpa Akuntabilitas Publik. (2009). Ikatan Akuntan Indonesia.

Tambunan, TTH. (2009). SME in Asean Developing Countries. Palgrive Macmillan. New York.

Undang-undang Republik Indonesia Nomor 20 Tahun 2008 tentang Usaha Mikro Kecil Menengah.

USAID. 2007. Booklet of Standardized Small and Medium Enterorises Definition. http://pdf.usaid.gov/pdf_does/PNADM 845.pdf. (diakses pada : 30 Januari 2016).

Wyk, HA Van \& J Rossouw. (2009). IFRS for SMEs in South Africa : A Giant Leap For Accounting, But Too Big For Smaller Entities in General. Meditari Accountancy research Vol 17 No. 1: 99116. 